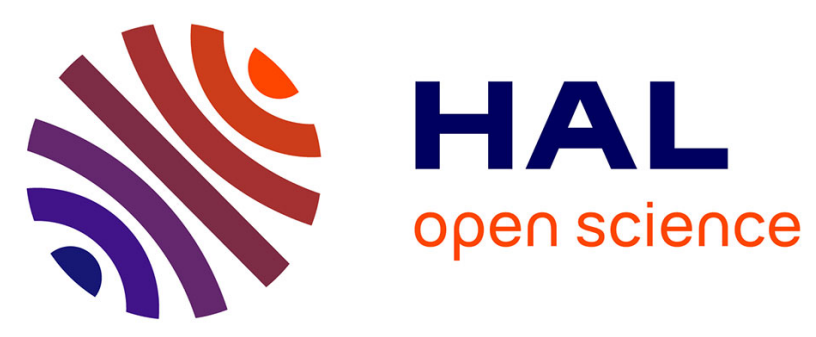

\title{
Rapid bacterial mineralization of organic carbon produced during a phytoplankton bloom induced by natural iron fertilization in the Soutern Ocean
}

Ingrid Obernosterer, Urania Christaki, Dominique Lefèvre, Philippe Catala, France van Wambeke, Philippe Lebaron

\section{To cite this version:}

Ingrid Obernosterer, Urania Christaki, Dominique Lefèvre, Philippe Catala, France van Wambeke, et al.. Rapid bacterial mineralization of organic carbon produced during a phytoplankton bloom induced by natural iron fertilization in the Soutern Ocean. Deep Sea Research Part II: Topical Studies in Oceanography, 2008, 55 (5-7), pp.777-789. 10.1016/j.dsr2.2007.12.005 . hal-00290755

\section{HAL Id: hal-00290755 \\ https://hal.science/hal-00290755}

Submitted on 18 Feb 2021

HAL is a multi-disciplinary open access archive for the deposit and dissemination of scientific research documents, whether they are published or not. The documents may come from teaching and research institutions in France or abroad, or from public or private research centers.
L'archive ouverte pluridisciplinaire HAL, est destinée au dépôt et à la diffusion de documents scientifiques de niveau recherche, publiés ou non, émanant des établissements d'enseignement et de recherche français ou étrangers, des laboratoires publics ou privés. 


\title{
Rapid bacterial mineralization of organic carbon produced during a phytoplankton bloom induced by natural iron fertilization in the Southern Ocean
}

\author{
Ingrid Obernosterer $^{\mathrm{a}, \mathrm{b}, *}$, Urania Christaki ${ }^{\mathrm{c}}$, Dominique Lefèvre ${ }^{\mathrm{d}}$, Philippe Catala ${ }^{\mathrm{a}, \mathrm{b}}$, \\ France Van Wambeke ${ }^{\mathrm{d}}$, Philippe Lebaron ${ }^{\mathrm{a}, \mathrm{b}}$ \\ ${ }^{\text {a } U P M C ~ U n i v ~ P a r i s ~ 06, ~ U M R ~ 7621, ~ L O B B, ~ O b s e r v a t o i r e ~ O c e ́ a n o l o g i q u e, ~ F-66651 ~ B a n y u l s / m e r, ~ F r a n c e ~}$ \\ ${ }^{\mathrm{b}} \mathrm{CNRS}$, UMR 7621, LOBB, Observatoire Océanologique, F-66651 Banyuls/mer, France \\ ${ }^{\mathrm{c}}$ Laboratoire d'Océanologie et de Géosciences, CNRS, UMR LOG 8187, Université du Littoral Côte d'Opale (MREN), 32 Avenue Foch, \\ 62930 Wimereux, France \\ Laboratoire de Microbiologie, Géologie et Ecologie Marine (LMGEM), CNRS 6117, Université de la Méditerranée, Campus de Luminy, Case \\ 901, 13288 Marseille Cedex 9, France
}

\begin{abstract}
The response of heterotrophic bacteria (Bacteria and Archaea) to the spring phytoplankton bloom that occurs annually above the Kerguelen Plateau (Southern Ocean) due to natural iron fertilization was investigated during the KErguelen Ocean and Plateau compared Study (KEOPS) cruise in January-February 2005. In surface waters (upper $100 \mathrm{~m}$ ) in the core of the phytoplankton bloom, heterotrophic bacteria were, on an average, 3-fold more abundant and revealed rates of production $\left(\left[{ }^{3} \mathrm{H}\right]\right.$ leucine incorporation) and respiration $(<0.8 \mu \mathrm{m}$ size fraction) that exceeded those in surrounding high-nutrient low-chlorophyll (HNLC) waters by factors of 6 and 5 , respectively. These differences in bacterial metabolic activities were attributable to high-nucleic-acid-containing cells that dominated $(\approx 80 \%$ of total cell abundance) the heterotrophic bacterial community associated with the phytoplankton bloom. Bacterial growth efficiencies varied between $14 \%$ and $20 \%$ inside the bloom and were $<10 \%$ in HNLC waters. Results from bottle-incubation experiments performed at the bloom station indicated that iron had no direct but an indirect effect on heterotrophic bacterial activity, due to the stimulation by phytoplankton-derived dissolved organic matter. Within the Kerguelen bloom, bacterial carbon demand accounted for roughly $45 \%$ of gross community production. These results indicate that heterotrophic bacteria processed a significant portion of primary production, with most of it being rapidly respired.
\end{abstract}

Keywords: Southern Ocean; Natural iron fertilization; Heterotrophic bacteria; High nucleic acid cells; Bacterial respiration; Bacterial growth efficiency

\section{Introduction}

Plankton respiration constrains the part of photosynthetically fixed carbon available for export to the ocean's interior. Bacteria (heterotrophic Bacteria and Archaea) account for a major part of plankton community respiration in the coastal and open ocean $(\approx 60 \%$; Robinson and

\footnotetext{
*Corresponding author at: Laboratoire d'Océanographie Biologique de Banyuls, CNRS, UMR7621, Avenue Fontaulé, BP 44, F-66650 Banyulssur-Mer, France.

E-mail address: ingrid.obernosterer@obs-banyuls.fr (I. Obernosterer).
}

Williams, 2005). Bacterial respiration of organic matter clearly dominates its incorporation into bacterial biomass, with most of the reported bacterial growth efficiencies (BGEs) varying between 5\% and 30\% (Del Giorgio and Cole, 2000). Bacterial heterotrophic production is tightly linked to local primary production across marine ecosystems (Cole et al., 1988; Ducklow, 2000); by contrast, the spatial and temporal variability in bacterial respiration is far less known. This lack of bacterial respiration rates renders present estimates of the portion of primary production passing through heterotrophic bacteria uncertain. 
In low-latitude marine environments, the close coupling between bacterial heterotrophic production and phytoplankton primary production appears to be less wellestablished, in particular during phytoplankton bloom events (Pomeroy and Deibel, 1986; Karl, 1993; Bird and Karl, 1999). The small and slow response of heterotrophic bacterial biomass production during phytoplankton blooms has been attributed to the low bioreactivity of dissolved organic matter (DOM; Billen and Becquevort, 1991), organic matter limitation (Carlson et al., 1998) or a higher sensitivity of heterotrophic bacteria than phytoplankton to low temperatures (Pomeroy and Deibel, 1986). A similar conclusion was drawn from results obtained during a mesocosm study performed in coastal Antarctic waters (Duarte et al., 2005). These authors attributed the weak coupling between bacteria and phytoplankton predominantly to the high growth rates of protists in cold waters resulting in a tight control of bacterial biomass production (Duarte et al., 2005). An idea that emerged from these studies is that during phytoplankton blooms in low-latitude marine environments the microbial food web is of minor importance due to the dominance of the classical food web.

The Southern Ocean represents the largest high-nutrient low-chlorophyll (HNLC) area in the global ocean (Sarmiento et al., 1998). Small- and mesoscale enrichment experiments have clearly identified iron as the primary limiting nutrient for phytoplankton growth (Boyd et al., 2000; Gervais et al., 2002; Coale et al., 2004). The intense phytoplankton blooms induced upon mesoscale iron addition to surface waters of the Southern Ocean were accompanied by much lower increases in heterotrophic bacterial abundance and production (Hall and Safi, 2001; Arrieta et al., 2004; Oliver et al., 2004). This lends support to the hypothesis of a weak coupling between phytoplankton and bacterial heterotrophic activity in low-temperature regions, suggesting a minor contribution of heterotrophic bacteria to the transformation of DOM from marine primary production.

The KErguelen Ocean and Plateau compared Study (KEOPS) cruise was designed to study the impact of natural iron fertilization on biogeochemical cycles in the Southern Ocean. Continuous supply of low quantities of iron and major nutrients above the Kerguelen Plateau sustained a massive phytoplankton bloom over roughly three months (Blain et al., 2007). The associated autotrophic (Armand et al., this issue) and heterotrophic (Christaki et al., this issue; Carlotti et al., this issue) communities revealed distinct features compared to those observed during short-term (weeks) mesoscale fertilizations. These features are likely related to the later successional stage of the Kerguelen bloom during the KEOPS-cruise (third month) with potentially important consequences for the cycling of carbon and nutrients.

Within the Kerguelen bloom, heterotrophic bacteria were more abundant and revealed substantially higher rates of production and respiration than in surrounding
HNLC waters. Roughly $45 \%$ of gross primary production was processed by heterotrophic bacteria, with most of it $(\sim 80 \%)$ being rapidly respired.

\section{Material and methods}

\subsection{Study sites}

The data reported here were collected at three study sites located above (Stations A3 and B5) and off the Kerguelen Plateau (Station C11), southeast of Kerguelen Island, in the Indian sector of the Southern Ocean (Fig. 1). Above the Kerguelen Plateau, one station (A3) was situated in the center of an intense phytoplankton bloom (Blain et al., 2007). Composite of MODIS and MERIS satellite images indicated the onset of this bloom roughly 2 months prior to the start of the KEOPS-cruise (January 19-February 13, 2005) and its collapse end of February. Station A3 was visited five times during the cruise, following the bloom from its peak to its decline. The parameters presented herein were determined during the first (A3-1), third (A3-3), fourth (A3-4) and fifth (A3-5) visits (Table 1), except for bacterial respiration (see the following text), which was not measured at Station A3-1. Station B5 was also located above the plateau roughly 100 nautical miles SE of Station A3 (Fig. 1). Based on composite of MODIS and MERIS satellite images received daily aboard the cruise vessel, we observed that surface chlorophyll $a$ concentrations were low at Station B5 at the beginning of the cruise, and they increased over a time period of roughly one week to concentrations similar to those at Station A3 (Mongin et al., this issue) (Fig. 2). This increase in chlorophyll $a$ concentrations at Station B5 was likely attributable to a pulsed phytoplankton bloom event just prior to the occupation of this site. Off the Kerguelen Plateau, one station (C11) representative of HNLC waters was sampled (Fig. 2).

Dissolved iron (DFe) concentrations were in the low nanomolar range $(\approx 0.1 \mathrm{nM})$ in surface waters on and off the plateau, but DFe increased rapidly with depth above the Kerguelen Plateau (Blain et al., this issue). The strong vertical DFe gradient and enhanced vertical mixing (Park et al., this issue) accounted for the on-going supply of iron from deep waters to surface waters above the plateau. Concentrations of major nutrients $\left(22-30 \mu \mathrm{M}\right.$ for $\mathrm{NO}_{3}^{-}$and $1.4-2.1 \mu \mathrm{M}$ for $\mathrm{PO}_{4}^{3-}$ ) were in the same range in the windmixed layer of the stations above and off the plateau (Mosseri et al., this issue). By contrast, silicate concentrations were by a factor of 10 higher in HNLC waters $(25 \mu \mathrm{M})$ than above the Kerguelen Plateau $(2 \mu \mathrm{M})$ (Mosseri et al., this issue). During the first visit to Station A3, concentrations of chlorophyll $a$ in the upper $100 \mathrm{~m}$ were 8-fold higher than at Station C11 (Table 1; Uitz et al., under revision).

Collection of seawater for the parameters presented herein was done with General Oceanics 12-L Niskin bottles mounted on a rosette equipped with a SeaBird 


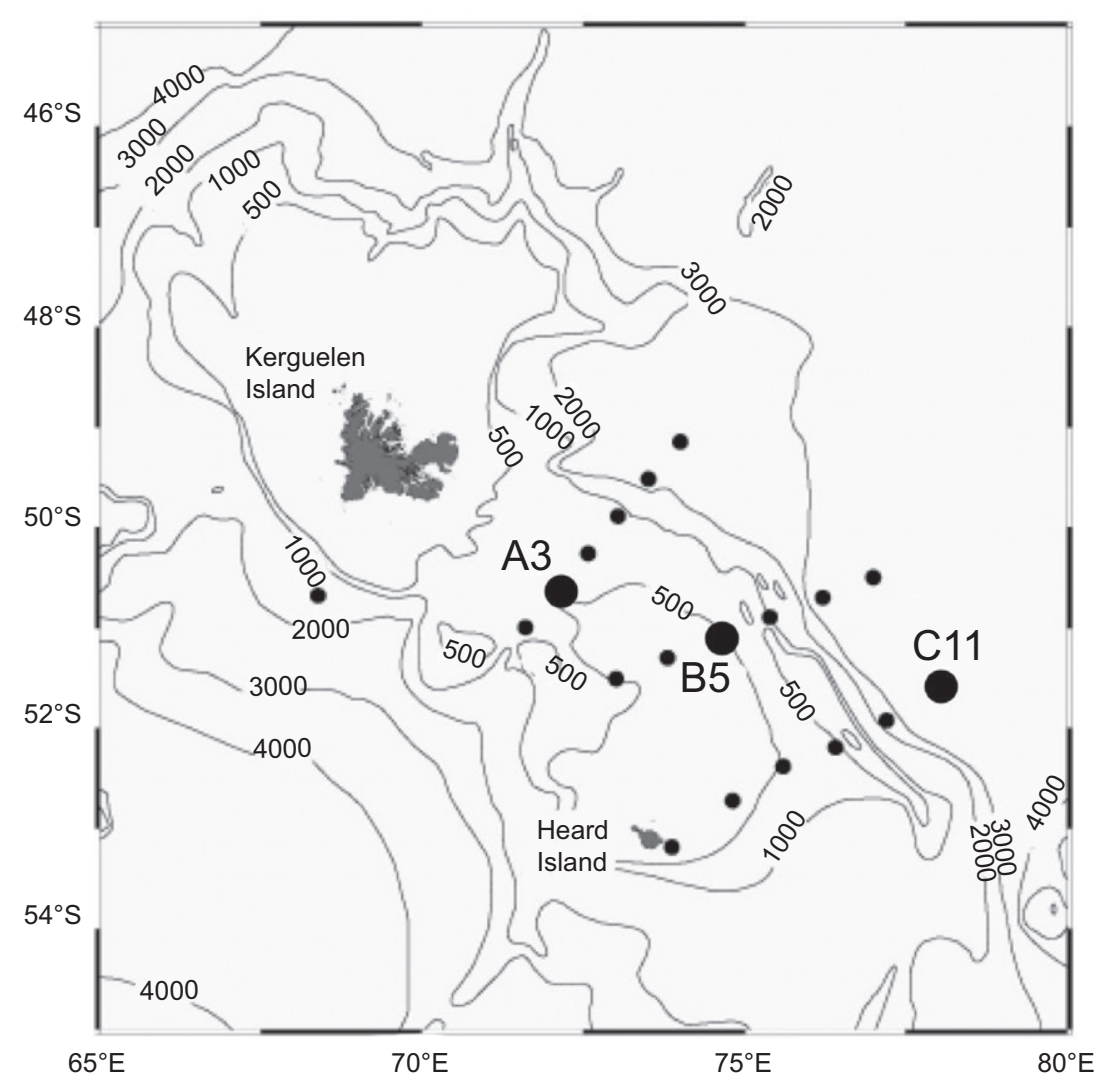

Fig. 1. Bathymetry of the Kerguelen Plateau with sampled Stations A3, B5 and C11 indicated by large dots. Small dots refer to the three transects carried out during the KEOPS-cruise.

Table 1

Brief description of the study sites

\begin{tabular}{|c|c|c|c|c|c|}
\hline Station & Date & Depth (m) & $\operatorname{MLD}(\mathrm{m})^{\mathrm{a}}$ & Temperature MLD $\left({ }^{\circ} \mathrm{C}\right)$ & Chlorophyll $a\left(\mu \mathrm{g} \mathrm{L}^{-1}\right)^{\mathrm{b}}$ \\
\hline A3-1 & 19 January & 527 & $52 \pm 12$ & 3.5 & $1.6 \pm 0.5$ \\
\hline A3-3 & 24 January & 527 & $51 \pm 14$ & 3.7 & $1.4 \pm 0.6$ \\
\hline A3-4 & 4 February & 527 & $79 \pm 20$ & 3.6 & $1.5 \pm 0.1$ \\
\hline A3-5 & 12 February & 527 & $84 \pm 19$ & 3.9 & $1.0 \pm 0.1$ \\
\hline B5 & 2 February & 527 & $84 \pm 16$ & 2.8 & $1.7 \pm 0.1$ \\
\hline $\mathrm{C} 11$ & 26 January & 2500 & $73 \pm 13$ & 2 & $0.2 \pm 0.1$ \\
\hline
\end{tabular}

MLD: wind-mixed layer.

${ }^{\mathrm{a}} \mathrm{The}$ wind-mixed layer is the mean $\pm \mathrm{SD}$ of all CTD casts performed during the occupation of the stations. The wind-mixed layer is based on a difference in sigma of 0.02 to the surface value.

${ }^{\mathrm{b}}$ Values are based on HPLC analysis (Uitz et al., under revision). Mean values \pm SD for the upper $100 \mathrm{~m}$ are given.

SBE19+ CTD. Seawater samples were transferred to polycarbonate (PC) bottles that were thoroughly rinsed with $\mathrm{HCl}(1 \%)$ and Milli-Q water before use.

\subsection{Bacterial respiration and bacterial growth efficiency $(B G E)$}

Rates of bacterial respiration were determined from changes in the dissolved oxygen $\left(\mathrm{O}_{2}\right)$ concentration during dark incubations of size-fractionated (Stations A3 and B5) and unfiltered seawater (Station C11). Seawater was collected at five or six depths in the upper $100 \mathrm{~m}$ and for size-fractionation experiments passed through $0.8-\mu \mathrm{m}$ polycarbonate filters (142 $\mathrm{mm}$ diameter, Poretics) using gravity-driven, reverse-flow filtration systems (Blight et al., 1995). The filtration system was thoroughly rinsed with sample water prior to collection of the $<0.8-\mu \mathrm{m}$ size fraction. The biological oxygen demand (BOD) bottles $(125 \mathrm{~mL})$ were filled by siphoning, using silicon tubing. During the dark incubation ( $24 \mathrm{~h}$ ), the BOD bottles were placed in an outdoor incubator supplied with running seawater to maintain in situ temperature. All measurements were performed in quadruplicate. Bacterial respiration was calculated as the difference between initial and final $\mathrm{O}_{2}$ concentrations as determined by Winkler titration of whole bottles. Titration was done using a PC-based system with a 

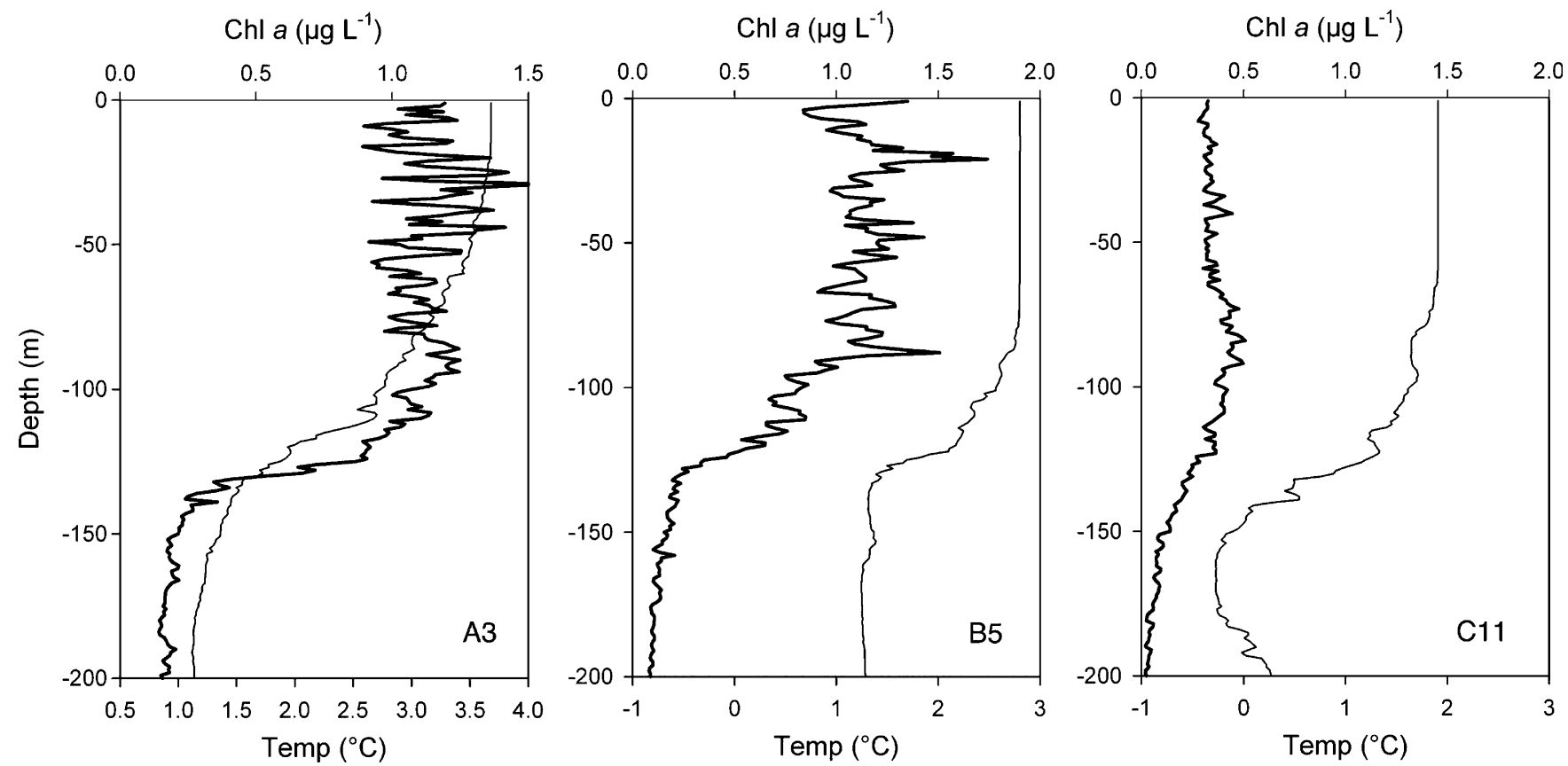

Fig. 2. Depth profiles of temperature (thin line) and chlorophyll $a$ (thick line) at Stations A3-3, B5 and C11. Chlorophyll $a$ values are derived from in situ fluorescence.

photometric endpoint detector (Williams and Jenkinson, 1982). For the data presented herein, the mean standard error and coefficient of variation of the measurements of the oxygen concentration performed prior and following the 24-h dark incubation were $0.11 \mu \mathrm{mol} \mathrm{O}_{2} \mathrm{~L}^{-1}$ $(0.037 \%, n=26)$ and $0.14 \mu \mathrm{mol} \mathrm{O}_{2} \mathrm{~L}^{-1}(0.042 \%, n=26)$, respectively.

To determine the BGE, bacterial production (BP; see the following text) was measured in $0.8-\mu \mathrm{m}$ filtered water prior to and following the 24-h incubation in BOD bottles as described earlier. In the course of the 24-h dark incubation, significant increases in bacterial production (by $109 \pm 37 \%$, $n=5$ ) were detectable only at Station A3-3. BGE was subsequently determined from bacterial respiration and the mean value of bacterial production determined prior and following the 24-h incubation of the $<0.8-\mu \mathrm{m}$ size fraction. To convert the $\mathrm{O}_{2}$ utilization rates into units of carbon, we applied respiratory quotients $\left(\mathrm{RQ}=\mathrm{CO}_{2}\right.$ produced $/ \mathrm{O}_{2}$ utilized) determined by concurrent measurements of $\mathrm{O}_{2}$ and $\mathrm{TCO}_{2}$ rates of dark community respiration of the respective study sites (Lefèvre et al., this issue). For Station A3, RQ were $0.89,0.83$ and 1.03 for the third, fourth and fifth visits, respectively. At Stations C11 and B5, we applied the mean RQ determined for all visits at Station $\mathrm{A} 3(\mathrm{RQ}=1)$. The standard error (SE) for the BGE was calculated as $\mathrm{SE}_{\mathrm{BGE}}=\left(R^{2} \times \mathrm{SE}_{\mathrm{P}}^{2}+P^{2} \times \mathrm{SE}_{\mathrm{R}}^{2}\right) /(P+R)^{-2}$, where $\mathrm{SE}_{\mathrm{P}}$ and $\mathrm{SE}_{\mathrm{R}}$ are the standard errors of the bacterial production $(P)$ and respiration $(R)$ measurements, respectively.

\subsection{Bacterial production measurement}

Bacterial production (BP) was determined by $\left[{ }^{3} \mathrm{H}\right]$ leucine incorporation applying the centrifugation method
(Smith and Azam, 1992). Briefly, 1.5-mL samples were incubated with a mixture of $\left[4,5-{ }^{3} \mathrm{H}\right]$ leucine (Amersham, specific activity $160 \mathrm{Ci} \mathrm{mmol}^{-1}$ ) and nonradioactive leucine at final concentrations of 7 and $13 \mathrm{nM}$, respectively. Samples were incubated in the dark at the respective in situ temperatures for 2-3h. Linearity of leucine incorporation over this time period was tested at the three stations. Incubations were terminated by the addition of trichloroacetic acid (TCA; Sigma) to a final concentration of $5 \%$. To facilitate the precipitation of proteins, bovine serum albumine (BSA; Sigma, $100 \mathrm{mg} \mathrm{L}^{-1}$ final concentration) was added prior to centrifugation at $16,000 \mathrm{~g}$ for 10 min (Van Wambeke et al., 2002). After discarding the supernatant, $1.5 \mathrm{~mL}$ of $5 \%$ TCA was added and the samples were subsequently vigorously shaken on a vortex and centrifuged again. The supernatant was discarded and $1.5 \mathrm{~mL}$ of PCS liquid scintillation cocktail (Amersham) was added. The radioactivity incorporated into bacterial cells was counted in a Packard LS 1600 Liquid Scintillation Counter. A factor of $1.55 \mathrm{~kg} \mathrm{Cmolleucine}{ }^{-1}$ was used to convert the incorporation of leucine to carbon equivalents, assuming no isotope dilution (Kirchman, 1993). Indeed, isotopic dilution ranged from 1.0 to 1.3 as determined on three occasions using a kinetic approach. Daily BP was calculated as 24 times the hourly rates.

\subsection{Flow cytometric analysis of heterotrophic bacteria}

For enumeration of heterotrophic bacteria, 3-mL subsamples of raw seawater were fixed with $2 \%$ formaldehyde (final concentration), stored in the dark at room temperature for $30 \mathrm{~min}$, and quick frozen in liquid nitrogen. Samples were stored at $80^{\circ} \mathrm{C}$ until analysis. A FACScalibur flow 
cytometer (Becton Dickinson, San Jose, CA) equipped with a 488-nm, 15-mW Argon laser was used for all flow cytometric analysis (Lebaron et al., 2001a). After thawing, samples were stained with the nucleic acid stain SYBR Green-I $(0.025 \%$ (v/v) final concentration, Molecular Probes). Stained bacteria were excited at $488 \mathrm{~nm}$ wavelength and discriminated according to their right anglelight scatter (SSC; related to cell size) and green fluorescence at $530 \pm 30 \mathrm{~nm}$ (FL1). The comparison between green and red fluorescence (FL3 $670 \mathrm{~nm}$ ) allowed discriminating the photosynthetic from nonphotosynthetic prokaryotes. The red fluorescence was subsequently eliminated for all cytogram analyses. Fluorescent beads (diameter, $1.002 \mu \mathrm{m}$; Polysciences Europe) were systematically added to each sample to normalize cell fluorescence and light scatter values. To determine the flow rate, a $1-\mathrm{mL}$ subsample was transferred to a $12 \times 75 \mathrm{~mm}$ plastic tube that was weighed before and after sample analysis during a defined time (generally $1 \mathrm{~min}$ ). The flow rate was determined several times during the analysis session. Regions were established on cytogram plots of side scatter versus green fluorescence to define high nucleic acid (HNA) and low nucleic acid (LNA) cells. To convert bacterial abundance to bacterial biomass, we applied a conversion factor of $12.4 \mathrm{fg} \mathrm{C} \mathrm{Cell}^{-1}$ (Fukuda et al., 1998).

\subsection{Iron-enrichment experiments}

To determine the role of DFe for bacterial heterotrophic activity above the Kerguelen Plateau, bottle-incubation experiments were performed at Station A3-4. Seawater was collected at $30 \mathrm{~m}$ using Goflo-bottles and transferred to a clean laboratory. Unfiltered seawater was subsequently distributed to 4-L PC bottles and amended with $\mathrm{FeCl}_{3}$ (1 $\mathrm{nM}$ final concentration). Unamended seawater incuba-

(A)

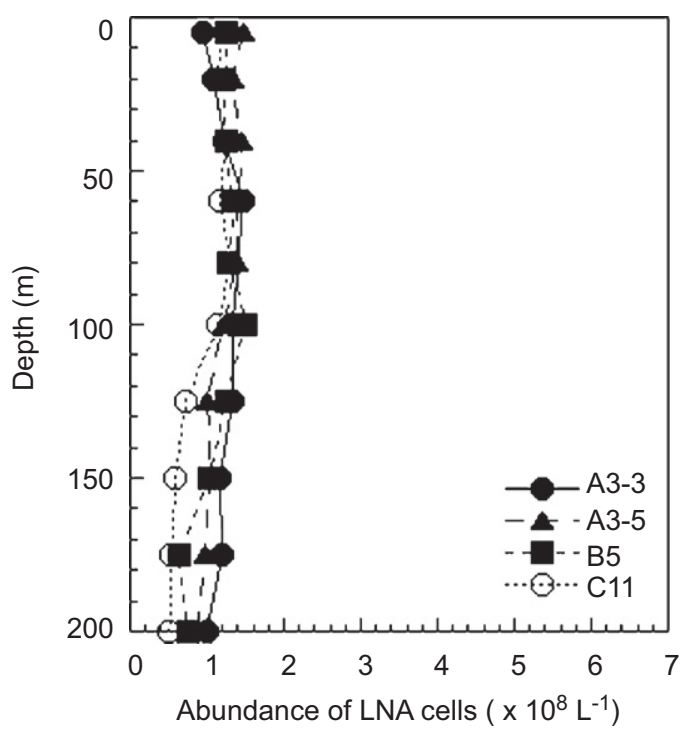

tions served as control. For each treatment, duplicate incubations were placed in an outdoor incubator at $50 \%$ surface solar radiation, representing the intensity of photosynthetic active radiation (PAR) at $7 \mathrm{~m}$ at A3-4. The incubations were kept at surface-water temperature by a running seawater system. The duration of the incubation was $9 \mathrm{~d}$, and every $3 \mathrm{~d}$ bacterial heterotrophic production and abundance and the concentration of chlorophyll $a$ were determined in duplicate PC bottles of each DFe and the control treatments. Concentrations of chlorophyll $a$ were determined aboard according to Raimbault et al. (1988) using a Turner Design fluorometer (TD Fluorometer $10.005 \mathrm{R})$.

\section{Results}

\subsection{Heterotrophic bacterial abundance and contribution of high nucleic acid cells}

Heterotrophic bacteria were homogenously distributed in the upper $100 \mathrm{~m}$, except for the third occupation of Station A3 (A3-3) where abundances peaked between 50 and $150 \mathrm{~m}$ (Fig. 3). Mean $( \pm$ SD) cell abundances in the upper $100 \mathrm{~m}$ were $6 \pm 1 \times 10^{8}$ cells L $^{-1}(n=5)$ at Station A3-3, 3.6 $\pm 0.2 \times 10^{8}$ cells L $^{-1}(n=6)$ at Station B5 and $2.3 \pm 0.2 \times 10^{8}$ cells L ${ }^{-1}(n=6)$ at Station C11. During the visits A3-1, A3-4 and A3-5, mean heterotrophic bacterial abundances for the upper $100 \mathrm{~m}$ varied between 4.3 and $5.5 \times 10^{8}$ cells $\mathrm{L}^{-1}$. Flow cytometric analysis revealed that HNA cells dominated the heterotrophic bacterial community above the Kerguelen Plateau, with relative contributions of HNA cells amounting to $81 \pm 3 \%(n=5)$ and $64 \pm 1 \%(n=6)$ at Stations A3-3 and B5, respectively. At Station A3, the percent contribution of HNA cells amounted to $84 \pm 1 \%$ during the first visit and decreased

(B)

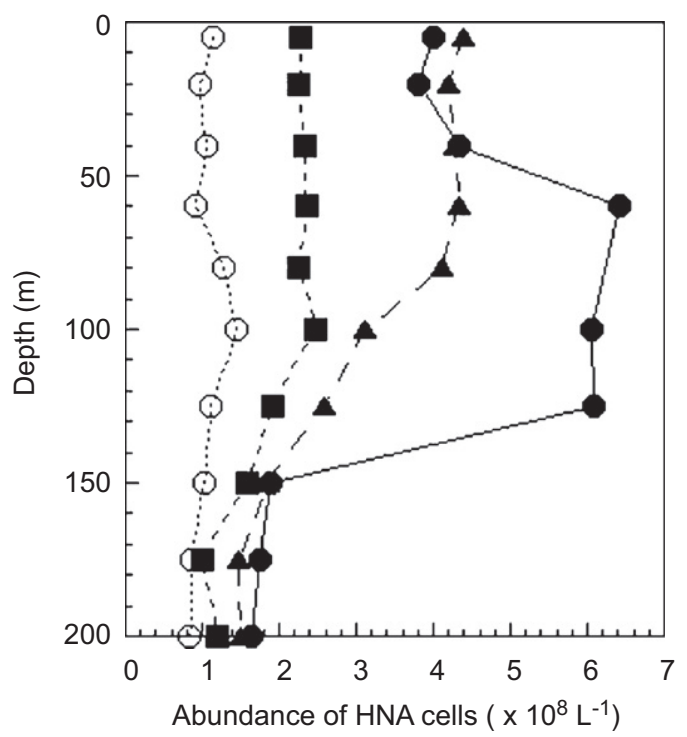

Fig. 3. Abundance of low (LNA) (A) and high nucleic acid (HNA) (B) cells within the Kerguelen bloom (Stations A3-3 and A3-5), at Station B5 and at the HNLC-site C11. 
slightly during the fourth $(75 \pm 2 \%, n=6)$ and fifth $(75 \pm 1 \%, n=6)$ occupation. By contrast, HNA cells had a substantially lower relative contribution in surface waters at Station $\mathrm{C} 11(48 \pm 4 \%, n=6)$. Interestingly, the percent contribution of HNA cells increased below $100 \mathrm{~m}$ at Station C11 accounting for roughly $60 \%$ of total bacterial abundance from 100 to $1000 \mathrm{~m}$ (data not shown). In terms of abundance, HNA cells were 5- and 2-fold, respectively, higher at Stations A3-3 and B5 than at Station C11, while abundances of LNA cells were similar in surface waters of the three study sites (Fig. 3).

\subsection{Heterotrophic bacterial production}

As for heterotrophic bacterial abundance, bacterial production was similar in the upper $100 \mathrm{~m}$ (Fig. 4A) and pronounced differences between the stations above the Kerguelen Plateau and the HNLC-site were again detectable. Mean $( \pm$ SD) rates of bacterial production at Stations A3-3 $\left(249 \pm 23 \mathrm{nmol} \mathrm{C} \mathrm{L}^{-1} \mathrm{~d}^{-1}, n=6\right)$ and B5 $(96 \pm 6$ nmolC $\mathrm{L}^{-1} \mathrm{~d}^{-1}, n=6$ ) were by factors of 6 and 2 , respectively, higher than at the HNLC-site C11 $\left(40 \pm 9 \mathrm{nmolC} \mathrm{L}^{-1} \mathrm{~d}^{-1}, n=6\right)$. During the first visit at A3, rates of bacterial production averaged $239 \pm 65$ $\mathrm{nmolC} \mathrm{L}{ }^{-1} \mathrm{~d}^{-1} \quad(n=5)$, and they decreased to $93 \pm 5 \mathrm{nmol} \mathrm{C} \mathrm{L}^{-1} \mathrm{~d}^{-1}(n=6)$ and $127 \pm 31 \mathrm{nmol} \mathrm{C} \mathrm{L}^{-1} \mathrm{~d}^{-1}$ $(n=6)$ at $\mathrm{A} 3-4$ and at A3-5, respectively. Cell-specific bacterial production rates (mean \pm SD) were $0.41 \pm 0.1$ and $0.27 \pm 0.02 \mathrm{fmolC} \mathrm{cell}^{-1} \mathrm{~d}^{-1}$ at Stations A3-3 and B5, respectively, and amounted to $0.17 \pm 0.03 \mathrm{fmol} \mathrm{C} \mathrm{cell}^{-1} \mathrm{~d}^{-1}$

(A)

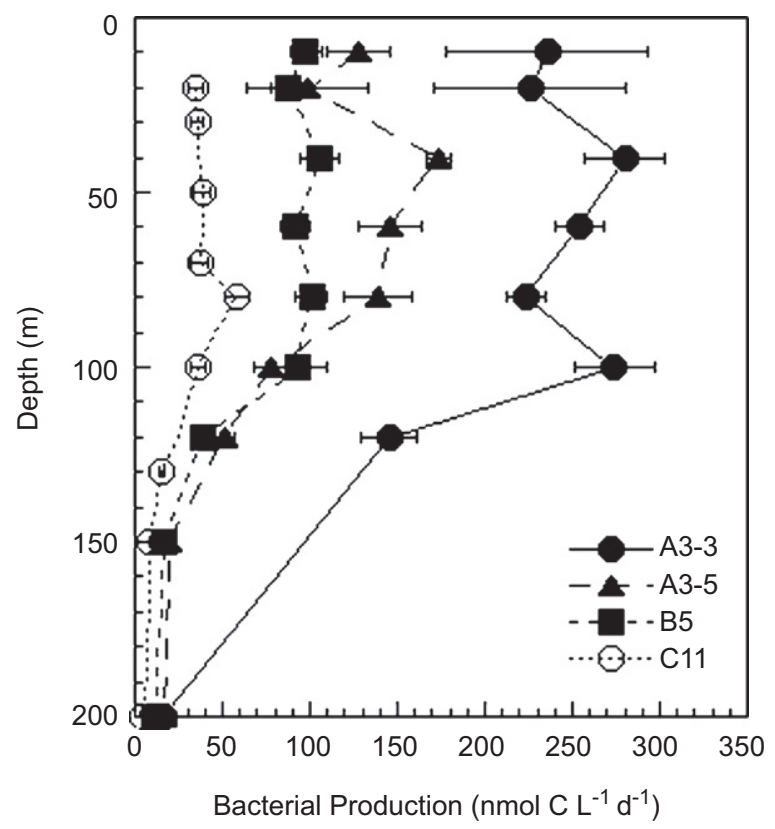

at Station C11 (Table 2). Above the Kerguelen Plateau, heterotrophic bacterial production was significantly correlated with the abundance of HNA cells $\left(r^{2}=0.761, n=52\right.$, $p=0.0001$ ), suggesting that predominantly HNA cells accounted for the high bacterial production at the bloom stations.

Growth rates of heterotrophic bacteria, determined by dividing bacterial production by cell biomass, varied between $0.40 \pm 0.1 \mathrm{~d}^{-1}$ at Station A3-3 and $0.26 \pm 0.02 \mathrm{~d}^{-1}$ at Station B5 and growth rates amounted to $0.17 \pm 0.03 \mathrm{~d}^{-1}$ at the HNLC-site C11 (Table 2).

\subsection{Heterotrophic bacterial respiration and growth efficiency}

Bacterial respiration was more variable throughout the upper $100 \mathrm{~m}$ (Fig. 4B), with highest respiration rates in the wind-mixed layer at Stations A3-3 $(51 \mathrm{~m}$, mean $\left.0.9 \pm 0.4 \mu \mathrm{mol} \mathrm{C} \mathrm{L}^{-1} \mathrm{~d}^{-1}, \quad n=5\right)$ and B5 $(84 \mathrm{~m}$, mean $\left.0.8 \pm 0.4 \mu \mathrm{mol} \mathrm{C} \mathrm{L}{ }^{-1} \mathrm{~d}^{-1}, n=4\right)$. At Station A3, respiration rates in the upper $100 \mathrm{~m}$ were lower during the fourth (mean $0.3 \pm 0.2 \mu \mathrm{molC} \mathrm{L}^{-1} \mathrm{~d}^{-1}, n=5$ ) and fifth (mean $\left.0.3 \pm 0.1 \mu \mathrm{mol} \mathrm{C} \mathrm{L} \mathrm{C}^{-1} \mathrm{~d}^{-1}, n=5\right)$ visits. At the HNLC-site C11, bulk respiration rates averaged $0.3 \pm 0.1 \mu \mathrm{mol}$ $\mathrm{CL}^{-1} \mathrm{~d}^{-1}(n=6)$ in the upper $100 \mathrm{~m}$. In contrast to bacterial production, no relationship between bacterial respiration and the abundance of HNA cells was detectable. Average cell-specific respiration rates in the upper $100 \mathrm{~m}$ were similar among Stations A3-3 (1.4 \pm $0.7 \mathrm{fmol} \mathrm{C}$ cell $\left.^{-1} \mathrm{~d}^{-1}\right)$, B5 $\left(1.9 \pm 1.3 \mathrm{fmol} \mathrm{C}\right.$ cell $\left.^{-1} \mathrm{~d}^{-1}\right)$ and

(B)

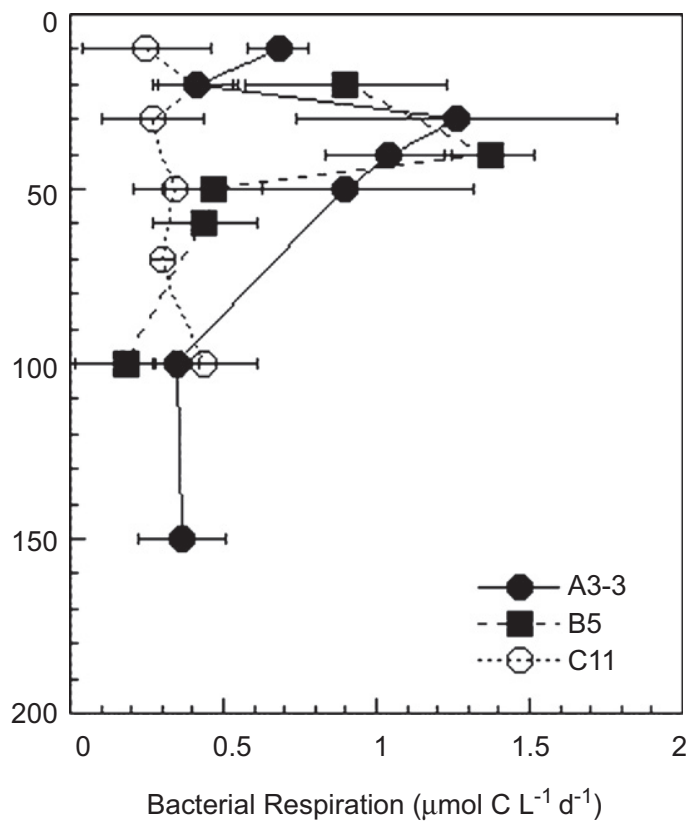

Fig. 4. Bacterial heterotrophic production (A) (mean values \pm percent variation of duplicate samples) and respiration (B) (mean values $\pm \mathrm{SE}$ of quadruplicate incubations) in surface waters above the Kerguelen Plateau (Stations A3 and B5) and at the HNLC-site C11. For clarity, only one depth profile of bacterial respiration is shown for Station A3. 
Table 2

Cell-specific bacterial heterotrophic production and growth rates, and cell-specific respiration rates in surface waters above the Kerguelen Plateau and at the HNLC-site

\begin{tabular}{|c|c|c|c|c|c|c|}
\hline \multirow[t]{2}{*}{ Station } & \multicolumn{5}{|l|}{ Kerguelen Plateau } & \multirow{2}{*}{$\begin{array}{l}\text { HNLC } \\
\text { C11 }\end{array}$} \\
\hline & A3-1 & A3-3 & A3-4 & A3-5 & B5 & \\
\hline $\begin{array}{l}\text { Cell-specific bacterial } \\
\text { production } \\
\left(\text { fmol }^{-1} \text { cell }\right. \\
\mu\left(\mathrm{d}^{-1}\right)\end{array}$ & $0.48 \pm 0.1(n=5)$ & $0.41 \pm 0.1(n=5)$ & $0.22 \pm 0.02(n=6)$ & $0.23 \pm 0.04(n=6)$ & $0.27 \pm 0.02(n=6)$ & $0.17 \pm 0.03(n=6)$ \\
\hline $\begin{array}{l}\text { Cell-specific bacterial } \\
\text { respiration } \\
\left(\mathrm{fmolC}^{-1} \mathrm{cell}^{-1} \mathrm{~d}^{-1}\right)\end{array}$ & n.d. & $1.4 \pm 0.7(n=5)$ & $0.7 \pm 0.4(n=5)$ & $0.5 \pm 0.2(n=5)$ & $1.9 \pm 1.3(n=5)$ & $1.5 \pm 0.2(n=6)$ \\
\hline
\end{tabular}

Mean values \pm SD of the upper $100 \mathrm{~m}$ are given.

Table 3

Bacterial growth efficiencies (BGE)

\begin{tabular}{|c|c|c|}
\hline Station & Depth (m) & BGE $(\%)$ \\
\hline A3-3 & $\begin{array}{l}10 \\
20 \\
30 \\
40 \\
60\end{array}$ & $\begin{array}{l}24 \pm 3 \\
32 \pm 6 \\
14 \pm 5 \\
14 \pm 2 \\
15 \pm 5\end{array}$ \\
\hline A3-4 & $\begin{array}{r}20 \\
40 \\
60 \\
80 \\
100\end{array}$ & $\begin{array}{c}22 \pm 13^{\mathrm{a}} \\
21 \pm 6 \\
13 \pm 5 \\
19 \pm 3 \\
8 \pm 2\end{array}$ \\
\hline A3-5 & $\begin{array}{r}10 \\
20 \\
40 \\
60 \\
100\end{array}$ & $\begin{array}{c}19 \pm 14^{\mathrm{a}} \\
16 \pm 6 \\
7 \pm 4 \\
18 \pm 6 \\
12 \pm 1\end{array}$ \\
\hline B5 & $\begin{array}{r}20 \\
40 \\
50 \\
60 \\
100\end{array}$ & $\begin{array}{c}4 \pm 1 \\
2 \pm 0.3 \\
12 \pm 3 \\
9 \pm 3 \\
9 \pm 6^{\mathrm{a}}\end{array}$ \\
\hline $\mathrm{C} 11$ & $\begin{array}{r}20 \\
30 \\
50 \\
70 \\
100\end{array}$ & $\begin{array}{l}4 \pm 3^{\mathrm{a}} \\
9 \pm 5^{\mathrm{a}} \\
8 \pm 3 \\
9 \pm 1 \\
1 \pm 0.6\end{array}$ \\
\hline
\end{tabular}

Mean values \pm SE of bacterial production and respiration rates are given.

${ }^{\mathrm{a}}$ The standard error of the respiration measurement is more than twice the respiration rate.

C11 $\left(1.5 \pm 0.2 \mathrm{fmol} \mathrm{C}\right.$ cell $\left.^{-1} \mathrm{~d}^{-1}\right)$ and substantially lower at Station A3-5 (0.5 $\pm 0.2 \mathrm{fmol} \mathrm{C}$ cell $\left.^{-1} \mathrm{~d}^{-1}\right)$ (Table 2).

The variability in the bacterial respiration was also reflected in the BGEs. Overall, BGE in the upper $100 \mathrm{~m}$ revealed slightly higher values at A3-3 (mean $20 \pm 8 \%$, $n=5$ ) than at A3-4 (mean $17 \pm 6 \%, n=5$ ) and at A3-5 $(14 \pm 5 \%, n=5)$ (Table 3). By contrast, BGEs were substantially lower at Station B5 $(7 \pm 4 \%, n=5)$ and at Station C11 (6 $\pm 3 \%, n=5)$ (Table 3).

\subsection{Iron-enrichment experiments}

Addition of DFe to unfiltered seawater collected in surface waters $(30 \mathrm{~m})$ at A3-4 had no effect on bacterial heterotrophic production during the first $6 \mathrm{~d}$ of incubation at $50 \%$ surface solar radiation (Fig. 5). At day 9 of the incubation, however, bacterial production was by a factor of 5 higher in the DFe treatment as compared to the unamended control. Similarly, bacterial abundance was not significantly different in the DFe treatment during the first $6 \mathrm{~d}$ of the incubation (data not shown). At day 9, bacterial abundance was 2.2-fold higher in the DFe treatment as compared to the unamended control. By contrast, phytoplankton biomass production rapidly responded to DFe addition. Concentrations of chlorophyll $a$ were 1.5- and 2.6-fold higher in the DFe treatment as compared to the unamended control after 3 and $6 \mathrm{~d}$ of incubation, respectively.

\section{Discussion}

We observed a firm response of heterotrophic bacteria to a phytoplankton bloom induced by natural iron fertilization in the Southern Ocean by substantial increases in biomass production and respiration as compared to surrounding HNLC waters. These differences in the metabolic activities were mainly attributable to HNAcontaining cells that dominated the bacterioplankton community associated with the phytoplankton bloom.

\subsection{Comparison to mesoscale Fe-fertilization experiments}

Heterotrophic bacterial activity within the Kerguelen bloom exhibited a clear temporal trend, with higher metabolic rates during the first and third occupations in January than during the fourth and fifth visits in February. This change over time is most likely related to the onset of the decline of the phytoplankton bloom, as indicated by pronounced decreases in chlorophyll $a$ concentrations (Table 1), biogenic silica production (Mosseri et al., this issue), and rates of specific gross community production 

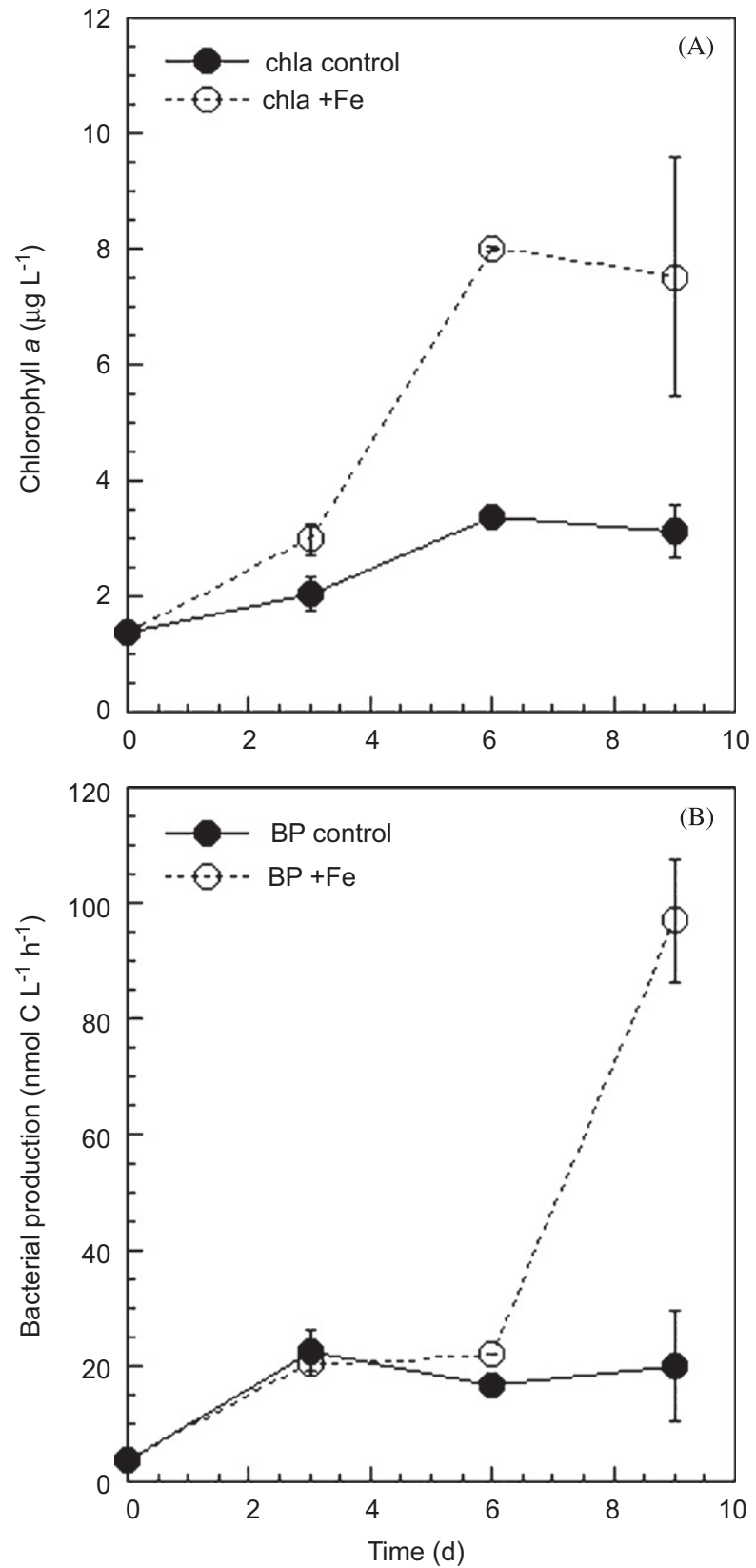

Fig. 5. Evolution of chlorophyll $a(\operatorname{chl} a)$ (A) and bacterial heterotrophic production (BP) (B) in seawater amended with $\mathrm{FeCl}_{3}(+\mathrm{Fe})$ and control treatments (control). All incubations were performed at $50 \%$ surface solar radiation. Mean values \pm percent variation of duplicate experiments performed at Station A3-4 are given.

(Lefèvre et al., this issue) during the last visit to Station A3. During the first visits in January, the enrichments in heterotrophic bacterial abundance $(\approx 3$-fold) and production $(\approx 6$-fold) within the Kerguelen bloom as compared to HNLC waters are well above those observed during previous mesoscale iron-addition experiments (Table 4). In terms of heterotrophic bacterial abundance, previous studies report no enhancement (Hall and Safi, 2001) or an increase varying between 1.5- and 2-fold within ironfertilized patches (Cochlan, 2001; Arrieta et al., 2004;
Oliver et al., 2004; Suzuki et al., 2005) (Table 4). Rates of bacterial heterotrophic production exceeded within all previous iron-fertilized patches those in surrounding waters by factors of 2-3 (Cochlan, 2001; Hall and Safi, 2001; Arrieta et al., 2004; Oliver et al., 2004) (Table 4). Interestingly, heterotrophic bacterial growth rates above the Kerguelen Plateau $\left(0.2-0.5 \mathrm{~d}^{-1}\right)$ (Table 2) are similar to those determined previously within iron-fertilized patches (0.1-0.4; Cochlan, 2001; Oliver et al., 2004), except for the particularly high growth rates $\left(0.4-1.5 \mathrm{~d}^{-1}\right)$ reported during SOIREE (Hall and Safi, 2001). This suggests that the turnover of a higher bacterial biomass distinguishes bacterial dynamics above the Kerguelen Plateau from that of mesoscale fertilization experiments.

\subsection{What stimulates heterotrophic bacterial activity above the Kerguelen Plateau?}

The continuous supply of low quantities of iron and major nutrients from below resulting in a 3-month phytoplankton bloom represents the major difference between the Kerguelen Plateau and mesoscale iron additions. Our observations of the response of heterotrophic bacteria to the phytoplankton bloom induced by this mode of natural fertilization are from the third month of the Kerguelen bloom, probably an important aspect to be considered for the comparison to mesoscale iron fertilizations occurring on shorter time scales (up to 40 days; Table 4). Lancelot et al. (1989) suggested a time lag between phytoplankton and heterotrophic bacteria of about 1 month to be characteristic for the Southern Ocean. Due to the later successional stage of the Kerguelen bloom compared to blooms induced by mesoscale iron addition, the associated food web structure revealed distinct features with a potentially important feedback on bacterial heterotrophic activity.

Above the Kerguelen Plateau, the plankton community rapidly utilized iron transported to surface waters as indicated by the low in situ DFe concentrations (Blain et al., this issue). Based on the high cellular iron quota of heterotrophic bacteria as compared to phytoplankton as revealed by $\mathrm{Fe}: \mathrm{C}$ ratios in excess by $1.5-2$ fold (Tortell et al., 1996), iron has been suggested to be an important factor in controlling heterotrophic bacterial activity in HNLC waters. Most dissolved iron ( $\mathrm{DFe}>90 \%$ ) is present in organically complexed form (Rue and Bruland, 1997) and iron-binding ligands (known as siderophores) facilitate the acquisition of this iron pool (Granger and Price, 1999). A recent study using a bacterial bioreporter suggests that at least some heterotrophic bacteria could have high-affinity systems to scavenge this organically bound iron (Mioni et al., 2005). These authors observed that Pseudomonas putida, a halotolerant isolate, responded faster to subtle increases in the ambient DFe pool (by $0.04 \mathrm{nM}$ ) than did the inherent phytoplankton community. Mioni et al. (2005) attributed this to a higher biological availability of the dissolved iron pool to heterotrophic bacteria than to 


\begin{tabular}{|c|c|c|c|c|c|c|c|}
\hline & \multirow[t]{2}{*}{ Temperature $\left({ }^{\circ} \mathrm{C}\right)$} & \multirow[t]{2}{*}{$\begin{array}{l}\text { Duration of } \\
\text { fertilization }(d)\end{array}$} & \multicolumn{2}{|c|}{$\begin{array}{l}\text { Bacterial abundance } \\
\left(\times 10^{8} \text { cells } \mathrm{L}^{-1}\right)\end{array}$} & \multicolumn{2}{|c|}{$\begin{array}{l}\text { Bacterial production } \\
\left(\mu \mathrm{g} \mathrm{C} \mathrm{L} \mathrm{L}^{-1} \mathrm{~d}^{-1}\right)\end{array}$} & \multirow[t]{2}{*}{ Reference } \\
\hline & & & Outside & Inside & Outside & Inside & \\
\hline \multicolumn{8}{|l|}{ Southern Ocean } \\
\hline KEOPS $\left(50^{\circ} \mathrm{S}, 72^{\circ} \mathrm{E}\right)$ & $3-4$ & $\approx 60$ & 2 & 6 & 0.5 & $1.1-3$ & This study \\
\hline EisenEx $\left(48^{\circ} \mathrm{S}, 21^{\circ} \mathrm{E}\right)$ & $3-4$ & 22 & $3-4$ & $2-6$ & $0.2-0.5$ & $0.2-1$ & Arrieta et al. (2004) \\
\hline SOIREE $\left(61^{\circ} \mathrm{S}, 140^{\circ} \mathrm{E}\right)$ & 2 & 13 & $2-4$ & $2-4$ & $<0.5$ & $0.4-1.1$ & Hall and Safi (2001) \\
\hline SOFEX-North $\left(56^{\circ} \mathrm{S}, 172^{\circ} \mathrm{W}\right)$ & 7 & 40 & $4-5$ & $7-10$ & 0.2 & 0.4 & Oliver et al. (2004) \\
\hline SOFEX-South $\left(66^{\circ} \mathrm{S}, 171^{\circ} \mathrm{W}\right)$ & -1 & 22 & 3 & $3-5$ & 0.2 & $0.2-0.3$ & Oliver et al. (2004) \\
\hline \multicolumn{8}{|l|}{ Subarctic Pacific } \\
\hline SEEDS $\left(49^{\circ} \mathrm{N}, 165^{\circ} \mathrm{E}\right)$ & $6-9$ & 13 & 5 & 8 & n.d. & n.d. & Suzuki et al. (2005) \\
\hline \multicolumn{8}{|l|}{ Equatorial Pacific } \\
\hline IronEx II $\left(5^{\circ} \mathrm{S}, 105^{\circ} \mathrm{W}\right)$ & 25 & 14 & 7 & 11 & $2-3$ & $2-8$ & Cochlan (2001) \\
\hline
\end{tabular}

Ranges of bacterial abundance and production are given for the wind-mixed layer of the respective study. All rates of bacterial production are derived from $\left[{ }^{3} \mathrm{H}\right]$ leucine incorporation, except for Hall and Safi (2001) who applied $\left[{ }^{3} \mathrm{H}\right]$ thymidine incorporation. Outside: values reported for HNLC waters; inside: values reported for iron-fertilized patches.

phytoplankton. This finding is coherent with shipboard experiments demonstrating that carbon is the primary limiting factor for heterotrophic bacterial growth in lowiron waters (Church et al., 2000; Kirchman et al., 2000), while only one study reports direct iron-limitation of heterotrophic bacteria in coastal Antarctic waters (Pakulski et al., 1996). Above the Kerguelen Plateau, addition of $1 \mathrm{nM} \mathrm{FeCl}{ }_{3}$ to surface waters did not stimulate bacterial production, while phytoplankton biomass rapidly increased (Fig. 5). The observed time lag between the increase in bacterial production behind that in phytoplankton biomass in the experiments performed in the present study supports the idea that above the Kerguelen Plateau heterotrophic bacteria were primarily stimulated by phytoplankton-derived DOM.

The more pronounced response of heterotrophic bacteria to the Kerguelen bloom as compared to mesoscale ironfertilization experiments could be related to the chemical composition and the supply rate of DOM. Previous ironfertilization experiments have not directly addressed this issue, and in the present study the BGE is the only estimate of these DOM characteristics. The BGEs determined within the Kerguelen bloom (14-20\%) are in the lower range of values reported for surface waters of the Antarctic Polar Front (26-30\%; Kähler et al., 1997) and for coastal Antarctic waters (9-38\%; Bjørnsen and Kuparinen, 1991; Carlson et al., 1999). This suggests no major differences in the availability and bioreactivity of DOM produced during the Kerguelen bloom and other Southern Ocean phytoplankton blooms. The lower BGEs determined at Station C11 $(\approx 6 \%$, Table 3$)$ indicate, however, that the quality and the supply rate of DOM were different at the HNLC-site.

Diatoms were the major phytoplankton biomass contributors above the Kerguelen Plateau and during most previous mesoscale iron fertilizations in the Southern Ocean (Armand et al., this issue; and references therein). The mechanisms that lead to DOM production could, however, have been different during KEOPS, as it was the only study where substantial mesozooplankton biomass and activity were observed (Carlotti et al., this issue). The additional supply of DOM by so-called "sloppy feeding" could have contributed to the enhancement of bacterial heterotrophic activity above the Kerguelen Plateau, suggesting that classical food web processes sustained a part of the microbial food web. An interesting feature observed within the Kerguelen bloom was that bacterial biomass production was predominantly controlled by viral lysis, while grazing of bacteria by heterotrophic nanoflagellates was of minor importance (Christaki et al., this issue; Malits and Weinbauer, unpublished data). Viral lysis of bacterial cells results mainly in the production of DOM that eventually will become available to heterotrophic bacteria. This viral loop enhances the cycling of carbon within the microbial loop and could have further stimulated bacterial activity above the Kerguelen Plateau. The bacterial community structure associated with the Kerguelen bloom revealed distinct differences compared to that in surrounding HNLC waters (West et al., 2008). Thus, the marked response in bulk characteristics such as bacterial production and respiration also could reflect the presence of a bacterial community that is well adapted to the environmental conditions above the Kerguelen Plateau, in particular to the DOM composition. The difference in the bacterial response to the Kerguelen bloom as compared to mesoscale iron additions is therefore most likely attributable to the continuous input of iron and major nutrients above the Kerguelen Plateau, the extent and duration of the phytoplankton bloom, and the DOM production that results thereof. 


\subsection{Linking bacterial activity to high nucleic acid cells}

A particular feature of the bacterial community above the Kerguelen Plateau was the dominance of HNA cells ( $\approx 80 \%$ of total cell abundance). By contrast, at Station C11 the fraction of HNA cells never exceeded $50 \%$ of total bacterial abundance. The relative contribution of HNA cells varies between $30 \%$ and $70 \%$ across a wide range of ecosystems, with higher percentages associated with high phytoplankton biomass (Gasol and Giorgio, 2000; Lebaron et al., 2001b; Del Giorgio and Bouvier, 2002; Sherr et al., 2006). The only study that has investigated the impact of iron fertilization on the abundance of HNA cells is that from Oliver et al. (2004) during SOFeX. These authors report a relatively minor increase of the fraction of HNA cells (up to $45 \%$ of total cell abundance) within the iron-fertilized patch (Oliver et al., 2004).

Sherr et al. (2006) suggested that variations in the percentage of HNA cells could be attributed to differences in the interactions within the microbial food web. As stated earlier, not grazing activity, but viral lysis predominantly regulated bacterial biomass production within the Kerguelen bloom (Christaki et al., this issue; Malits and Weinbauer, unpublished data.). We hypothesize that the importance of HNA cells within the Kerguelen bloom can, at least to some part, be attributed to a low grazing pressure that preferentially affects HNA cells due to their larger biovolume.

There is presently a lively debate whether HNA cells, due to their higher nucleic acid content, reveal higher metabolic activities than LNA cells (Jellet et al., 1996; Gasol et al., 1999). Results on the cell-specific activity of the two subpopulations using cell-sorting techniques are, however, contradictory with HNA cell-specific activities being considerably higher (Lebaron et al., 2001a; Servais et al., 2003) or similar (Longnecker et al., 2005; Zubkov et al., 2001) to those of LNA cells. In the present study, it was interesting to note that differences in the total cell abundance between the two contrasting Stations A3 and C11 were uniquely attributable to a higher abundance in HNA cells above the Kerguelen Plateau, while the abundances of LNA cells were similar at all stations (Fig. 3). This observation and the robust relationship between the HNA cell abundance and bacterial production (see also Christaki et al., this issue) strongly suggest that HNA cells were mainly responsible for the high bacterial production above the Kerguelen Plateau.

\subsection{Carbon flow through heterotrophic bacteria}

Above the Kerguelen Plateau, the bacterial carbon demand equaled $\approx 55 \%$ and $\approx 45 \%$ of primary production and gross community production, respectively (Table 5). These results, obtained during both the third month of an intense spring phytoplankton bloom (Station A3) and a pulsed phytoplankton bloom event (Station B5), suggest a strong coupling between phytoplankton and bacterial heterotrophic activity. The firm response of heterotrophic bacteria to the Kerguelen bloom is further supported by a strong relationship between phytoplankton biomass and heterotrophic bacterial biomass and production across the study area (Christaki et al., this issue). For comparison, common ratios of bacterial to phytoplankton biomass and bacterial to primary production applied to the present data

Table 5

Bacterial and phytoplankton stocks and fluxes integrated over the wind-mixed layer above the Kerguelen Plateau and at the HNLC-site

\begin{tabular}{|c|c|c|c|c|c|c|}
\hline & \multicolumn{5}{|c|}{ Kerguelen Plateau } & $\begin{array}{l}\text { HNLC } \\
\text { C11 }\end{array}$ \\
\hline \multicolumn{7}{|l|}{ Stocks $\left(\mathrm{mmol} \mathrm{Cm}^{-2}\right)$} \\
\hline Bacterial biomass & 25 & 27 & 35 & 49 & 30 & 17 \\
\hline Phytoplankton biomass ${ }^{\mathrm{a}}$ & 328 & 202 & 447 & 466 & 406 & 130 \\
\hline \multicolumn{7}{|l|}{ Fluxes $\left(\mathrm{mmolCm}^{-2} \mathrm{~d}^{-1}\right)$} \\
\hline Bacterial carbon demand & $55^{\mathrm{b}}$ & 54 & 28 & 32 & 75 & 31 \\
\hline Primary production $^{\mathrm{c}}$ & 88 & 85 & 89 & 81 & 91 & 21 \\
\hline Gross community production ${ }^{\mathrm{d}}$ & 138 & 80 & 80 & 101 & 133 & 25 \\
\hline BCD:PP & 0.63 & 0.64 & 0.31 & 0.40 & 0.82 & 1.48 \\
\hline
\end{tabular}

BB - Bacterial biomass, PB - Phytoplankton Biomass, BP—Bacterial heterotrophic production, PP — primary production, GCP-Gross community production.

${ }^{a}$ Phytoplankton biomass is based on microscopic observations (Armand et al., this issue).

${ }^{\mathrm{b}}$ The bacterial carbon demand is based on the mean BGE of $20 \%$ determined for A3-3.

${ }^{\mathrm{c}}$ Primary production is based on ${ }^{13} \mathrm{C}$ incorporation (Mosseri et al., this issue).

${ }^{\mathrm{d}}$ Gross community production is based on $\mathrm{TCO}_{2}$ rates except for Stations $\mathrm{B} 5$ and $\mathrm{C} 11$ where $\mathrm{O}_{2}$ rates were converted to C-units applying a PQ of 1.2 (Lefèvre et al., this issue). 
set remain low $(\approx 0.1)$. Lochte et al. (1997) observed regional differences in the fraction of spring primary production passing through heterotrophic bacteria, amounting to $30 \%$ in the polar frontal zone and the marginal ice zone and up to $66 \%$ in the southern Antarctic Circumpolar Current. Based on measurements of photosynthetic extracellular release that equaled the estimated bacterial carbon demand in low productive off-shore Antarctic waters, Moran et al. (2001) concluded that heterotrophic bacteria were tightly linked to phytoplankton activity. These results and the present study suggest that the relation between phytoplankton and bacterioplankton is variable in the Southern Ocean, but not necessarily different from that observed in temperate regions.

\subsection{Implications for the recycling of iron}

Above the Kerguelen Plateau, heterotrophic bacteria represented a relatively small, but dynamic pool of biogenic iron (Sarthou et al., this issue). Grazing by heterotrophic nanoflagellates or viral lysis of bacterial cells results both in the regeneration of the major part of iron bound in bacterial cells (Strzepek et al., 2005). Based on a bacterial turnover rate of $3.5 \mathrm{~d}$ (mean for all visits at Station A3) and a bacterial iron quota of $7.5 \mu \mathrm{mol} \mathrm{Fe}\left(\mathrm{mol} \mathrm{C}^{-1}\right)$ (Tortell et al., 1996), we estimated an iron regeneration of $\sim 1 \mathrm{pmol}$ $\mathrm{Fe} \mathrm{L}^{-1} \mathrm{~d}^{-1}$ for surface waters above the Kerguelen Plateau. This value compares to an iron regeneration of $\sim 1.5 \mathrm{pmol}$ $\mathrm{Fe} \mathrm{L}^{-1} \mathrm{~d}^{-1}$ due to mesozooplankton grazing as determined from ${ }^{55} \mathrm{Fe}$-addition experiments (Sarthou et al., this issue). The grazer- and virus-mediated release of iron from bacterial cells reinforces the idea of the microbial ferrous wheel (Kirchman, 1996) within the phytoplankton bloom above the Kerguelen Plateau, suggesting that bacteria could play an important role in maintaining DFe in surface seawater.

\section{Acknowledgments}

We thank the project coordinator S. Blain (CNRS, Université de la Mediterranée, Marseille) for inviting us to participate in the KEOPS project and the chief scientist B. Quéguiner and the captain and the crew of the R/V Marion Dufresne for their support aboard. C. Guigue excellently performed dissolved oxygen analyses and L. Armand kindly provided Fig. 1. We also thank J. Mosseri for the preparation of the clean bottle-incubation experiments and B. Griffiths for chlorophyll $a$ measurements. Two anonymous reviewers helped improve an earlier version of the manuscript. Financial support for this work came from the French National program PROOF (INSU/CNRS) and the Institut Polaire Emile Victor (IPEV).

\section{References}

Armand, L., Cornet-Barthau, V., Mosseri, J., Quéguiner, B. Late summer diatom biomass and community structure on and around the naturally iron-fertilized Kerguelen Plateau in the Southern Ocean. Deep-Sea Research II, this issue [doi:10.1016/j.dsr2.2007.12.031].

Arrieta, J.M., Weinbauer, M., Lute, C., Herndl, G.J., 2004. Response of bacterioplankton to iron fertilization in the Southern Ocean. Limnology and Oceanography 49, 799-808.

Billen, G., Becquevort, S., 1991. Phytoplankton-bacteria relationship in the Antarctic marine ecosystem. Polar Research 10, 245-253.

Bird, D.F., Karl, D.M., 1999. Uncoupling of bacteria and phytoplankton during the austral spring bloom in Gerlache Strait, Antarctic Peninsula. Aquatic Microbial Ecology 19, 13-27.

Bjørnsen, P.K., Kuparinen, J., 1991. Determination of bacterioplankton biomass, net production and growth efficiency in the Southern Ocean. Marine Ecology Progress Series 71, 185-194.

Blain, S., Quéguiner, B., Armand, L.K., Belviso, S., Bombled, B., Bopp, L., Bowie, A., Brunet, C., Brussaard, C., Carlotti, F., Christaki, U., Shreeve, R.S., Corbière, A., Durand, I., Ebersbach, F., Fuda, J.L., Garcia, N., Gerringa, L., Griffiths, B., Guigue, C., Guillerm, C., Jacquet, S., Jeandel, C., Laan, P., Lefèvre, D., Lomonaco, C., Malits, A., Mosseri, J., Obernosterer, I., Park, H.Y., Picheral, M., Pondaven, P., Remenyi, T., Sandroni, V., Sarthou, G., Savoye, N., Scouarnec, L., Souhaut, M., Thuiller, D., Timmermans, K., Trull, T., Uitz, J., VanBeek, P., Veldhuis, M., Vincent, D., Viollier, E., Vong, L., Wagener, T., 2007. Impact of natural iron fertilisation on carbon sequestration in the Southern Ocean. Nature 446, 1070-1074.

Blain, S., Sarthou, G., Laan, P. Distribution of dissolved iron during the natural iron fertilisation experiment KEOPS (Kerguelen Plateau, Southern Ocean). Deep-Sea Research II, this issue [doi:10.1016/ j.dsr2.2007.12.028].

Blight, S.P., Bentley, T.L., Lefèvre, D., Robinson, C., Rodrigues, R., Rowlands, J., Williams, P.J.leB., 1995. Phasing of autotrophic and heterotrophic plankton metabolism in a temperate coastal ecosystem. Marine Ecology Progress Series 128, 61-75.

Boyd, P.W., Watson, A., Law, C.S., Abraham, E., Trull, T., Murdoch, R., Bakker, D.C.E., Bowie, A.R., Charette, M., Croot, P., Downing, K., Frew, R., Gall, M., Hadfield, M., Hall, J., Harvey, M., Jameson, G., La Roche, J., Liddicoat, M., Ling, R., Maldonado, M., McKay, R.M., Nodder, S., Pickmere, S., Pridmore, R., Rintoul, S., Safi, K., Sutton, P., Strzepek, R., Tannenberger, K., Turner, S., Waite, A., Zeldis, J., 2000. A mesoscale phytoplankton bloom in the polar Southern Ocean stimulated by iron fertilization. Nature 407, 695-702.

Carlotti, F., Thibault-Botha, D., Nowaczyk, A., Lefèvre, D. Zooplankton community structure, biomass and role in carbon fluxes during the second half of a phytoplankton bloom in the eastern sector of the Kerguelen shelf (January-February 2005). Deep-Sea Research II, this issue [doi:10.1016/j.dsr2.2007.12.010].

Carlson, C.A., Ducklow, H.W., Smith, W.O., Hansell, D.A., 1998. Organic carbon partitioning during spring phytoplankton blooms in the Ross Sea polynya and the Sargasso Sea. Limnology and Oceanography 43, 375-386.

Carlson, C.A., Bates, N.R., Ducklow, H.W., Hansell, D.A., 1999. Estimation of bacterial respiration and growth efficiency in the Ross Sea, Antarctica. Aquatic Microbial Ecology 19, 229-244.

Christaki, U., Obernosterer, I., Van Wambeke, F., Veldhuis, M.J.W., Garcia, N., Catala, P. Microbial food web structure in a naturally iron fertilized area in the Southern Ocean (Kerguelen Plateau). Deep-Sea Research II, this issue [doi:10.1016/j.dsr2.2007.12.009].

Church, M.J., Hutchins, D.A., Ducklow, H.W., 2000. Limitation of bacterial growth by dissolved organic matter and iron in the Southern Ocean. Applied and Environmental Microbiology 66, 455-466.

Coale, K.H., Johnson, K.S., Chavez, F.P., Buesseler, K.O., Barber, R.T., Brzezinski, M.A., 2004. Southern Ocean iron enrichment experiment: carbon cycling in high-and low-Si waters. Science 304, 408-414.

Cochlan, W.P., 2001. The heterotrophic bacterial response during a mesoscale iron enrichment experiment (IronEx II) in the eastern equatorial Pacific Ocean. Limnology and Oceanography 46, 428-435.

Cole, J.J., Findlay, S., Pace, M.L., 1988. Bacterial production in fresh and saltwater ecosystems: a cross-system overview. Marine Ecology Progress Series 43, 1-10. 
Del Giorgio, P.A., Bouvier, T.C., 2002. Linking the physiologic and phylogenetic successions in free-living bacterial communities along an estuarine salinity gradient. Limnology and Oceanography 47, 471-486.

Del Giorgio, P.A., Cole, J.J., 2000. Bacterial energetics and growth efficiency. In: Kirchman, D.L. (Ed.), Microbial Ecology of the Oceans. Wiley-Liss, Inc., pp. 289-325.

Duarte, C.M., Agusti, S., Vaqué, D., Agawin, N.S.R., Felipe, J., Casamayor, E.O., Gasol, J.M., 2005. Experimental test of bacteriaphytoplankton coupling in the Southern Ocean. Limnology and Oceanography 50, 1844-1854.

Ducklow, H., 2000. Bacterial production and biomass in the oceans. In: Kirchman, D.L. (Ed.), Microbial Ecology of the Oceans. Wiley-Liss, Inc., pp. 85-121.

Fukuda, R., Ogawa, H., Nagata, T., Koike, I., 1998. Direct determination of carbon and nitrogen contents of natural bacterial assemblages in marine environments. Applied and Environmental Microbiology 64, 3352-3358.

Gasol, J.M., Giorgio, P.A.D., 2000. Using flow cytometry for counting natural planktonic bacteria and understanding the structure of planktonic bacterial communities. Scientia Marina 64, 197-224.

Gasol, J.M., Zweifel, U.L., Peters, F., Fuhrman, J.A., Hagström, A., 1999. Significance of size and nucleic acid content heterogeneity as measured by flow cytometry in natural planktonic bacteria. Applied and Environmental Microbiology 65, 4475-4483.

Gervais, F., Riebesell, U., Gorbunov, M.Y., 2002. Changes in primary productivity and chlorophyll a in response to iron fertilization in the southern Polar Frontal Zone. Limnology and Oceanography 47, 1324-1335.

Granger, J., Price, N.M., 1999. The importance of siderophores in iron nutrition of marine bacteria. Limnology and Oceanography 44, $541-555$.

Hall, J.A., Safi, K., 2001. The impact of in situ Fe fertilisation on the microbial food web in the Southern Ocean. Deep-Sea Research Part II: Topical Studies in Oceanography 48, 2591-2613.

Jellet, J.F., Li, W.K.W., Dickie, P.M., Boraie, A., Kepley, P.E., 1996. Metabolic activity of bacterioplankton communities assessed by flow cytometry and single carbon substrate utilization. Marine Ecology Progress Series 136, 213-225.

Kähler, P., Bjornsen, P.K., Lochte, K., Antia, A., 1997. Dissolved organic matter and its utilization by bacteria during spring in the Southern Ocean. Deep-Sea Research Part I 44, 341-353.

Karl, D.M., 1993. Microbial processes in the Southern Oceans. In: Friedman, E.I. (Ed.), Antarctic Microbiology. Wiley-Liss, Inc., pp. 11-63.

Kirchman, D., 1993. Leucine incorporation as a measure of biomass production by heterotrophic bacteria. In: Kemp, P.F., Sherr, B.F., Sherr, E.B., Cole, J.J. (Eds.), Handbook of Methods in Aquatic Microbial Ecology. Lewis, Boca Raton, pp. 509-512.

Kirchman, D., 1996. Microbial ferrous wheel. Nature 383, 303-304.

Kirchman, D., Meon, B., Cottrell, M.T., Hutchins, D.A., Weeks, D., Bruland, K.W., 2000. Carbon versus iron limitation of bacterial growth in the Californian upwelling regime. Limnology and Oceanography $45,1681-1688$.

Lancelot, C., Billen, G., Mathot, S., 1989. Ecophysiology of phyto-and bacterioplankton growth in the Southern Ocean. Belgian Scientific Research Program on Antarctica-scientific results of phase one (October 1985-January 1989). Plankton Ecology 1, 1-97.

Lebaron, P., Servais, P., Agogue, H., Courties, C., Joux, F., 2001a. Does the high nucleic acid content of individual bacterial cells allow us to discriminate between active cells and inactive cells in aquatic systems? Applied and Environmental Microbiology 67, 1775-1782.

Lebaron, P., Servais, P., Troussellier, M., Courties, C., Muyzer, G., Bernard, L., Schaefer, H., Pukall, R., Stackebrandt, E., Guindulain, T., Vives-Rego, J., 2001b. Microbial community dynamics in Mediterranean nutrient-enriched seawater mesocosms: changes in abundances, activity and composition. FEMS Microbiology Ecology $34,255$.

Lefèvre, D., Guigue, C., Obernosterer, I. The metabolic balance at two contrasting sites in the Southern Ocean: The iron-fertilized Kerguelen area and HNLC waters. Deep-Sea Research II, this issue [doi:10.1016/ j.dsr2.2007.12.006].

Lochte, K., Bjørnsen, P.K., Giesenhagen, H., Weber, A., 1997. Bacterial standing stock and production and their relation to phytoplankton in the Southern Ocean. Deep-Sea Research Part II 44, 321-340.

Longnecker, K., Sherr, B.F., Sherr, E.B., 2005. Activity and phylogenetic diversity of high and low nucleic acid content, and ETS active, bacterial cells in an upwelling ecosystem. Applied and Environmental Microbiology 71, 7730-7749.

Mioni, C.E., Handy, S.M., Ellwood, M.J., Twiss, M.R., McKay, R.M.L., Boyd, P.W., Wilhelm, S.W., 2005. Tracking changes in bioavailable Fe within high-nitrate low-chlorophyll oceanic waters: a first estimate using a heterotrophic bacterial bioreporter. Global Biogeochemical Cycles, doi:10.1029/2005GB002476.

Mongin, M., Molina, E., Trull, T. Seasonality and scale of the Kerguelen Plateau phytoplankton bloom: a remote sensing and modeling analysis if the influence of natural iron fertilization in the Southern Ocean. Deep-Sea Research II, this issue [doi:10.1016/j.dsr2.2007.12.039].

Moran, X.A.G., Gasol, J.M., Pedros-Alio, C., Estrada, M., 2001. Dissolved and particulate primary and bacterial production in offshore Antarctic waters during austral summer: coupled or uncoupled? Marine Ecology Progress Series 222, 25-39.

Mosseri, J., Quéguiner, B., Armand, L., Cornet-Barthau, V. Impact of iron on silicon utilization by diatoms in the Southern Ocean: a case of $\mathrm{Si} / \mathrm{N}$ cycle decoupling in a naturally iron-enriched area. Deep-Sea Research II, this issue [doi:10.1016/j.dsr2.2007.12.003].

Oliver, J.L., Barber, R.T., W.O. Smith, J., Ducklow, H.W., 2004. The heterotrophic bacterial response during Southern Ocean Iron Experiment (SOFeX). Limnology and Oceanography 49, 2129-2140.

Pakulski, J.D., Coffin, R.B., Kelley, C.A., Holder, S.L., 1996. Iron stimulation of Antarctic bacteria. Nature 383, 133-134.

Park, Y.H., Fuda, J.L., Durand, I., Naveira Garabato, A.C. Internal tides and vertical mixing over the Kerguelen Plateau. Deep-Sea Research II, this issue [doi:10.1016/j.dsr2.2007.12.027].

Pomeroy, L., Deibel, D., 1986. Temperature regulation of bacterial activity during the spring bloom in Newfoundland coastal waters. Science 233, 359-361.

Raimbault, P., Taupier-Letage, I., Rodier, M., 1988. Vertical size distribution of phytoplankton in the western Mediterranean Sea during early summer. Marine Ecology Progress Series $45(1 / 2)$, 153-158.

Robinson, C., Williams, P.J.leB., 2005. Respiration and its measurement in surface marine waters. In: del Giorgio, P., Williams, P.J.leB. (Eds.), Respiration in Aquatic Ecosystems. Oxford University Press, pp. 147-180.

Rue, E.L., Bruland, K.W., 1997. The role of organic complexation on ambient iron chemistry in the equatorial Pacific Ocean and the response of a mesoscale iron addition experiment. Limnology and Oceanography 42, 901-910.

Sarmiento, J.L., Hughes, C.W., Stouffer, R.J., Manabe, S., 1998 Simulated response of the ocean carbon cycle to anthropogenic climate warming. Nature 393, 245-249.

Sarthou, G., Vincent, D., Christaki, U., Obernosterer, I., Timmermans, K.R., Brussaard, C.P.D. The fate of biogenic iron during a phytoplankton bloom induced by natural fertilization: impact of copepod grazing. Deep-Sea Research II, this issue [doi:10.1016/j.dsr2. 2007.12.033].

Servais, P., Casamayor, E.O., Courties, C., Catala, P., Parthuisot, N., Lebaron, P., 2003. Activity and diversity of bacterial cells with high and low nucleic acid content. Aquatic Microbial Ecology 33, $41-51$.

Sherr, E.B., Sherr, B.F., Longnecker, K., 2006. Distribution of bacterial abundance and cell-specific nucleic acid content in the Northeast Pacific Ocean. Deep-Sea Research Part I 53, 713-725.

Smith, D.C., Azam, F., 1992. A simple, economical method for measuring bacterial protein synthesis rates in sea water using ${ }^{3} \mathrm{H}$-leucine. Marine Microbial Food Webs 6, 107-114. 
Strzepek, R.F., Maldonado, M.T., Higgins, J.L., Hall, J., Safi, K., Wilhelm, S.W., Boyd, P.W., 2005. Spinning the "Ferrous Wheel": the importance of the microbial community in an iron budget during FeCycle experiment. Global Biogeochemical Cycles 19, doi:10.1029/ 2005 GB002490.

Suzuki, K., Hinuma, A., Saito, H., Kiyosawa, H., Liu, H., Saino, T., Tsuda, A., 2005. Responses of phytoplankton and heterotrophic bacteria in the northwest subarctic Pacific to in situ iron fertilization as estimated by HPLC pigment analysis and flow cytometry. Progress in Oceanography 64, 167-187.

Tortell, P.D., Maldonado, M.T., Price, N.M., 1996. The role of heterotrophic bacteria in iron-limited ocean ecosystems. Nature 383, 330-332.

Uitz, J., Claustre, H., Garcia, N., Griffiths, B.F., Ras, J., Sandroni, V. A phytoplankton class-specific primary production model applied to the Kerguelen Islands region (Southern Ocean) (under revision).
Van Wambeke, F., Christaki, U., Giannakourou, A., Moutin, T., Souvemerzoglou, K., 2002. Longitudinal and vertical trends of bacterial limitation by phosphorus and carbon in the Mediterranean Sea. Microbial Ecology 43, 119-133.

West, N.J., Obernosterer, I., Zemb, O., Lebaron, P., 2008. Major differences of bacterial diversity and activity inside and outside of a naturally iron-fertilized phytoplankton bloom in the Southern Ocean. Environmental Microbiology 10, 738-756.

Williams, P.J.leB., Jenkinson, N.W., 1982. A transportable microprocessor-controlled precise Winkler titration suitable for field station and shipboard use. Limnology and Oceanography 27, 576-584.

Zubkov, M.V., Fuchs, B.M., Burkhill, P.H., Amann, R., 2001. Comparison of cellular and biomass specific activities of dominant bacterioplankton groups in stratified waters of the Celtic Sea. Applied and Environmental Microbiology 67, 5210-5218. 